\title{
Article
}

\section{Protein Extraction and Stripping with Calixarene Derivatives}

\author{
Tatsuya OSHIMA, Hiroaki HIGUCHI, Keisuke OHTO and Katsutoshi INOUE \\ Department of Applied Chemistry, Faculty of Science and Engineering, \\ Saga University, 1-Honjo, Saga 840-8502, Japan \\ Masahiro GOTO \\ Department of Applied Chemistry, Graduate School of Engineering, \\ Kyushu University, Hakozaki, Fukuoka 812-8581, Japan
}

(Manuscript submitted February 15, 2003; accepted April 22, 2003)

\begin{abstract}
Solvent extraction of cationic proteins with calix[n]arene carboxylic acid derivatives ( $\mathrm{n}$ $=4,6,8)$ has been examined. The calix[6]arene, which has a strong affinity to protonated amino groups on the surface of protein, showed the highest extractability for cytochrome $\mathrm{c}$ at low extractant concentration. Spectroscopic analysis of the extracted protein suggested that the tertiary structure is different by the type of calixarenes. Only a "Lys-rich protein" cytochrome c was effectively extracted with the calix[6]arene, while other proteins tend to aggregate in the aqueous phase. Stripping of the extracted cytochrome $\mathrm{c}$ was achieved with an acidic solution containing ethanol.
\end{abstract}

\section{Introduction}

Liquid - liquid extraction of proteins has been developed with reversed micelle system since 1980's. Various proteins can be transferred into reversed micelle solution, and the extraction mechanisms has been clarified in detail.[1] However, the separation factor is generally low because the simple electrostatic interaction between the protein and the surfactant head groups governs the protein transfer. In some cases, selective extraction has been achieved with affinity reversed micelle system by using an affinity ligand to bind a target protein. For instance, concanavalin $\mathrm{A}$ is selectively extracted from a mixture of proteins with reversed micelle system incorporated with alkylglucoside as an affinity ligand.[2] Therefore, characteristic of the ligand is one of the most important factors for the selective extraction of a protein.

Authors have developed a series of calixarene carboxylic acid derivatives as extractants for various metal ions or organic molecules such as amino acids.[3,4] A calixarene has a cavity to include a guest molecule and shows a specific interaction to the target by introducing various functional groups. For recognition of an organic molecule, calix[6]arene or calix[8]arene is favorable due to their lager cavity. Recently, it was found that a calix[6]arene carboxylic acid derivative (abbreviated as ${ }^{\mathrm{t}} \mathrm{Oct}[6] \mathrm{CH}_{2} \mathrm{COOH}$ ) functions as an extractant for a hemeprotein cytochrome $\mathrm{c}$ (abbreviated as Cyt-c).[5] The extractant strongly acts with a cationic residue on the surface of a protein by including it into the cavity to form a hydrophobic complex. Thus calixarene is expected as a platform to create a recognition tool for biopolymers.[6] The present study examines solvent extraction of cationic proteins with calix[n]arene carboxylic acid derivatives $(n=4,6,8)$ to elucidate the structural factors for the extraction. Stripping of the extracted Cyt-c into an aqueous solution was also carried out. 


\section{Experimental}

\subsection{Materials}

The structures and abbreviations of calixarene series and a monomer analog used in this study are shown in Fig. 1. They were synthesized according to the procedure described in the previous papers. [3,4] Protein reagents for the solvent extraction experiments were purchased and employed without further purification: i.e., Cyt-c from horse heart, ribonuclease A (RibA) from bovine pancreas, (Sigma-Aldrich Co. St. Louis, MO), and lysozyme (Lyso) from egg white (Nacalai Tesque, Inc. Kyoto, Japan). All other reagents were of reagent grade.

\subsection{Solvent Extraction Study}

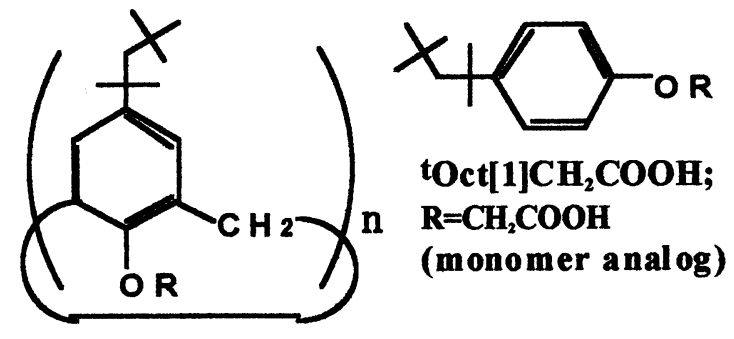

toct [4] $\mathrm{CH}_{2} \mathrm{COOH} ; n=4, \mathrm{R}=\mathrm{CH}_{2} \mathrm{COOH}$

(cone conformation)

toct[6]CH $\mathrm{CH}_{2} \mathrm{COOH} ; \mathrm{n}=6, \mathrm{R}=\mathrm{CH}_{2} \mathrm{COOH}$

toct $[8] \mathrm{CH}_{2} \mathrm{COOH} ; \mathrm{n}=8, \mathrm{R}=\mathrm{CH}_{2} \mathrm{COOH}$

Fig. 1 Molecular structures of calixarenes and the monomer analog used in this study

An aqueous solution was prepared by dissolving a protein. An organic solution was prepared by dissolving an extractant into chloroform or isooctane containing 10 vol\% of 1 -octanol. Both phases $\left(5 \mathrm{~cm}^{3}-5\right.$ $\mathrm{cm}^{3}$ ) were mixed in a stoppered test tube and gently shaken for $24 \mathrm{~h}$ to reach the equilibrium state at $30^{\circ} \mathrm{C}$. After the phase separation, the concentration of the protein in the aqueous phase was measured by an HPLC (Waters 515-2487 isocratic system) or a UV-vis spectrometer (PerkinElmer LAMBDA 190) to determine the degree of extraction $\left.\left(\mathrm{E}=1-[\text { Protein }]_{\mathrm{aq}, \mathrm{eq}} / \text { [Protein }\right]_{\mathrm{aq}, \mathrm{ini}}\right)$. Stripping of extracted Cyt-c was carried out as follows: After an operation of the forward extraction $\left(50 \mathrm{~cm}^{3}-50 \mathrm{~cm}^{3}\right)$, an organic solution containing $9 \times 10^{-3} \mathrm{~mol} / \mathrm{m}^{3}$ of Cyt-c was obtained. The organic phase $\left(5 \mathrm{~cm}^{3}\right)$ was contacted with a fresh aqueous phase $\left(5 \mathrm{~cm}^{3}\right)$ for $24 \mathrm{~h}$. Both phases were separated and the concentration of Cyt-c in stripping solution was quantified to determine the degree of back-extraction (B.E.).

\section{Results and discussion}

\subsection{Extraction of cationic proteins with calixarenes}

Figure 2 shows the extraction of Cyt-c with various carboxylic acid extractants. The data are plotted with absorbance of Soret band of extracted Cyt-c in the organic phase as ordinate and the molar ratio between extractant and protein as abscissa. The calix[6]arene ${ }^{\mathrm{t}} \mathrm{Oct}[6] \mathrm{CH}_{2} \mathrm{COOH}$ provides the highest extractability in the all extractants and Cyt-c was quantitatively extracted in the presence of 20 -fold equivalent of the extractant. The performance of the calix[8]arene ${ }^{\mathrm{t} O c t}[8] \mathrm{CH}_{2} \mathrm{COOH}$ is next to ${ }^{\mathrm{t}} \mathrm{Oct}[6] \mathrm{CH}_{2} \mathrm{COOH}$, while that of the calix[4]arene ${ }^{\mathrm{t} O c t}[4] \mathrm{CH}_{2} \mathrm{COOH}$ is much lower. Furthermore, the monomer analog ${ }^{t} \mathrm{Oct}[1] \mathrm{CH}_{2} \mathrm{COOH}$ does not extract Cyt-c at all.



Fig. 2 Dependency of [tOct $\left.[n] \mathrm{CH}_{2} \mathrm{COOH}\right] /[$ Cyt-c] ratio for the extraction of Cyt-c: [Cyt-c] $]_{\text {ini }}=10 \mu \mathrm{mol} / \mathrm{dm}^{3}, \mathrm{pH}_{\mathrm{ini}}$ 6.2: ${ }^{\mathrm{t}} \mathrm{Oct}[1] \mathrm{CH}_{2} \mathrm{COOH}(\boldsymbol{\Delta}),{ }^{\mathrm{t}} \mathrm{Oct}[4] \mathrm{CH}_{2} \mathrm{COOH}(\mathrm{O})$, 'Oct[6]CH $\mathrm{CH}_{2} \mathrm{COOH}(\mathbf{O}),{ }^{\mathrm{t}} \mathrm{Oct}[8] \mathrm{CH}_{2} \mathrm{COOH}(\triangle)$. 
affinity between the extractant and Cyt-c conclusively dominates the extractability. The order of extraction for Cyt-c ('Oct[6] $\mathrm{CH}_{2} \mathrm{COOH}>{ }^{\mathrm{t}} \mathrm{Oct}[8] \mathrm{CH}_{2} \mathrm{COOH}>{ }^{\mathrm{t}} \mathrm{Oct}[4] \mathrm{CH}_{2} \mathrm{COOH}>{ }^{\mathrm{t}} \mathrm{Oct}[1] \mathrm{CH}_{2} \mathrm{COOH}$ ) agrees with that for amino acids in our previous study.[5] The molecules are extracted by the interaction between the protonated amino group $\left(-\mathrm{NH}_{3}{ }^{+}\right)$and the extractant. ${ }^{t} \mathrm{Oct}[6] \mathrm{CH}_{2} \mathrm{COOH}$ has a strong affinity to $-\mathrm{NH}_{3}{ }^{+}$due to the ideal cavity size, the $\mathrm{C}_{3}$ symmetry, and preorganized carboxylic acid groups for inclusion of it. Therefore Cyt-c is extracted with ${ }^{\mathrm{t} O c t}[6] \mathrm{CH}_{2} \mathrm{COOH}$ through the complexations between $-\mathrm{NH}_{3}{ }^{+}$group of the lysine residue in Cyt-c and the extractant. ${ }^{t} \mathrm{Oct}[8] \mathrm{CH}_{2} \mathrm{COOH}$ is also able to include $-\mathrm{NH}_{3}{ }^{+}$group in the cavity, however, the recognition is not strict because the cavity size is too large. On the other hand, ${ }^{t} \mathrm{Oct}[4] \mathrm{CH}_{2} \mathrm{COOH}$ is hard to include $-\mathrm{NH}_{3}{ }^{+}$group due to the small cavity. In addition, hydrophobicity of the complex between the protein and the extractant is also a key factor for the extraction. Since the monomer analog ${ }^{\mathrm{t}} \mathrm{Oct}[1] \mathrm{CH}_{2} \mathrm{COOH}$ cannot afford the sufficient hydrophobicity to extract Cyt-c, the precipitate is formed at the oil-water interface.

UV-vis and CD spectra of the extracted Cyt-c in chloroform are summarized in Table 1 as well as those of native Cyt-c in water, in order to investigate the effect of complexation on the structural changes of Cyt-c. For Cyt-c extracted with ${ }^{\mathrm{t}} \mathrm{Oct}[6] \mathrm{CH}_{2} \mathrm{COOH}$ or ${ }^{\mathrm{t}} \mathrm{Oct}[8] \mathrm{CH}_{2} \mathrm{COOH}$, the Soret band is shifted to lower wavelength. While, the Soret band of Cyt-c extracted with ${ }^{\mathrm{t}} \mathrm{Oct}[4] \mathrm{CH}_{2} \mathrm{COOH}$ is rarely shifted and the $\mathrm{CD}$ spectrum pattern is quite different. These results suggests that the tertiary structure of Cyt-c extracted with ${ }^{\mathrm{t}} \mathrm{Oct}[4] \mathrm{CH}_{2} \mathrm{COOH}$ is different to those extracted with ${ }^{\mathrm{t}} \mathrm{Oct}[6] \mathrm{CH}_{2} \mathrm{COOH}$ and ${ }^{\mathrm{t}} \mathrm{Oct}[8] \mathrm{CH}_{2} \mathrm{COOH}$.

Table 1 UV-vis and CD Spectra of Native Cyt-c in Water or Extracted Cyt-c in chloroform

\begin{tabular}{|c|c|c|c|c|}
\hline \multirow[b]{2}{*}{ Sample } & \multicolumn{3}{|c|}{$\lambda \max$} & \multirow{2}{*}{$\begin{array}{l}C D \text { spectrum patterns } \\
\text { at Soret band region }\end{array}$} \\
\hline & $\begin{array}{c}\text { Soret } \\
\text { band [nm] }\end{array}$ & $\begin{array}{c}\text { Q-band } \alpha / \beta \\
{[\mathrm{nm}]}\end{array}$ & $\begin{array}{c}\text { S-Fe charge } \\
\text { transfer }(695 \mathrm{~nm})\end{array}$ & \\
\hline Native Cyt-c & 409 & 528 & yes & $\begin{array}{l}\text { a negative }(419 \mathrm{~nm}) \text { and a positive }(410 \mathrm{~nm}) \text { peak } \\
\text { (a Split cotton effect) }\end{array}$ \\
\hline Cyt-c extracted with ${ }^{t} \mathrm{Oct} 44 \mathrm{JCH}_{2} \mathrm{COOH}$ & 409 & broaden & no & $\begin{array}{l}\text { a positive }(420 \mathrm{~nm}) \text {, a negative }(410 \mathrm{~nm}) \text {, } \\
\text { and a positive }(396 \mathrm{~nm}) \text { peak }\end{array}$ \\
\hline Cyt-c extracted with ${ }^{t} \mathrm{Oct}[6] \mathrm{CH}_{2} \mathrm{COOH}$ & 402 & broaden & no & a broaden positive peak \\
\hline Cyt-c extracted with ${ }^{t} \mathrm{Oct}[8] \mathrm{CH}_{2} \mathrm{COOH}$ & 400 & broaden & no & a broaden positive peak \\
\hline
\end{tabular}

Extraction behaviors of three cationic proteins with ${ }^{\mathrm{t}} \mathrm{Oct}[6] \mathrm{CH}_{2} \mathrm{COOH}$ into the isooctane solution are shown in Fig. 3. While Cyt-c is quantitatively extracted at more than $\mathrm{pH} 4$, the extractions of RibA and Lyso are much smaller. In addition, they tend to aggregate in the aqueous phase.

Theses cationic proteins are similar in molecular weight but different in the number of lysine residue; 19 for Cyt-c, 10 for RibA, and 6 for Lyso. Cyt-c is transferred by forming a hydrophobic complex with several ${ }^{\mathrm{O}} \mathrm{Oct}[6] \mathrm{CH}_{2} \mathrm{COOH}$ molecules. In contrast, RibA or Lyso binds with fewer extractants. Due to the small hydrophobicity, the complex remains in the aqueous phase to form the precipitate. Namely, tOct[6] $\mathrm{CH}_{2} \mathrm{COOH}$ extracts only a "Lys-Rich protein".



Fig. 3 Extraction profiles of cationic proteins with 'Oct [6] $\mathrm{CH}_{2} \mathrm{COOH}$ : [protein] ini $=1.0 \mathrm{~g} / \mathrm{dm}^{3}$, $\left[{ }^{\mathrm{t} O \mathrm{Oct}}[6] \mathrm{CH}_{2} \mathrm{COOH}\right]=3.0 \mathrm{mmol} / \mathrm{dm}^{3}$. 


\subsection{Stripping of Cytochrome $\mathrm{c}$ from organic solution}

Next step for separation and purification of proteins is stripping it into a fresh aqueous solution. Since the driving force of the extraction is electrostatic interaction, usually the extract can be recovered by contacting an aqueous acidic solution.

Figure 4 exhibits the extraction profile of Cyt-c with ${ }^{t} \mathrm{Oct}[6] \mathrm{CH}_{2} \mathrm{COOH}$ as well as the back extraction profile by contacting a fresh acidic solution. The extracted Cyt-c is not recovered by contacting just an acidic solution which is unfavorable to extraction. That is, the transfer of Cyt-c into the organic phase seems to be an irreversible process. In case of reversed micelle system, addition of an alcohol helps the stripping of proteins in such a situation. Therefore the stripping experiment examined again with adding $15 \mathrm{vol} \%$ of ethanol in a stripping solution. As shown in the figure, the back-extraction proceeded by addition of $15 \mathrm{vol} \%$ of ethanol, and quantitative stripping is achieved at less than $\mathrm{pH}$ 2. Cyt-c extracted with ${ }^{\mathrm{t}} \mathrm{Oct}[8] \mathrm{CH}_{2} \mathrm{COOH}$ was also recovered with an acidic solution containing $15 \mathrm{vol} \%$ of ethanol (data not shown).

These results suggest that several conditions are required for the stripping of Cyt-c from the calixarene solution. Adjusting lower $\mathrm{pH}$ condition can promote the dissociation of the complex between the extractant and Cyt-c. However, the complex is hard to approach to oil/water interface, due to the hydrophobicity. Addition of an alcohol, which exhibits the intermediate characteristic between water and organic solvents, convert their properties to similar ones. Consequently, the complex becomes to approach the interface and the stripping reaction is proceeded.

In conclusion, extraction and recovery of a cationic protein cytochrome $\mathrm{c}$ have been achieved. The calixarene derivatives are attractive as a new separation tool for proteins.

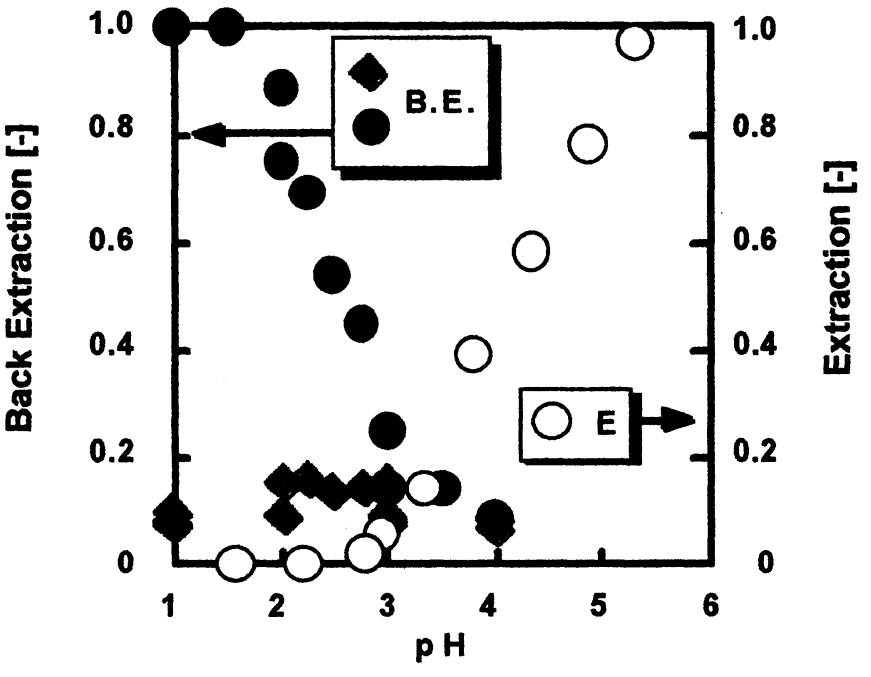

Fig. 4 Extraction and back-extraction profiles of Cyt-c in isooctane media ( containing $10 \mathrm{vol} \%$ 1-octanol ): Extraction (O), Back Extraction (alcohol free) (*), Back Extraction (15 vol\% ethanol) (O).

\section{Acknowledgement}

The authors gratefully acknowledge the financial support from a Grand-in-Aid for Scientific Research (Fundamental Research B, No. 14350419) from Ministry of Education, Science, Sports and Culture of Japan.

\section{References}

1) M, J. Pires, M. R. Aires-Barros, J. M. S. Cabral, Biotech. Prog., 12, 290-301 (1996)

2) M. Adachi, M. Harada, A. Shioi, H. Takahashi, S. Katoh, J. Chem. Eng. Jpn., 29, 982-989 (1996)

3) K. Ohto, M. Yano, K. Inoue, T. Yamamoto, M. Goto, F. Nakashio, S. Shinkai, T. Nagasaki, Anal. Sci., 11, 893-902 (1995)

4) T. Oshima, M. Goto, S. Furusaki, J. Incl. Phenom., 43, 77-86 (2002)

5) T. Oshima, M. Goto, S. Furusaki, Biomacromolecules, 3(3), 438-444 (2002)

6) M. W. Peczuh, A. D. Hamilton, Chem. Rev., 100, 2479-2494 (2000) 